\title{
WTO and the Dynamics of Free Trade: The Challenges of International Trade Law in a Divided Economic World
}

\begin{abstract}
By Isaac O. C. Igwe*
The relationship between free trade, globalisation, global poverty and global inequality for the past decades has generated interests from academics, free trade activists, public financial institutions like the WTO, the World Bank, the IMF, and the Organisation for Economic Cooperation and Development (OECD). Consequently, there has being divergent views and conclusions on whether free trade and globalisation actually benefit all countries of the world especially the developing world. This paper will examine the intent of global free trade agenda and how it affects the contemporary International market interaction between developed and developing economies. The paper will explore International trade obstacles, articulate policies that will maximize developing countries competitiveness, increased connectivity, improved trade access to markets and advocate ways to facilitate their participation in the global economy.
\end{abstract}

Keywords: WTO; World Bank; IMF; Free Trade; Globalisation; Global Poverty; Inequality; Developing Countries.

\section{Introduction}

The American new economic order was introduced after the Cold War to revamp the economy of other countries, but was intrinsically geared towards creating a western economic empire. The introduction of a free market philosophy, termed 'the great transformation', brought changes to the economic activities of many countries, including Great Britain. ${ }^{1}$ It influenced the structural frameworks and policies of transnational organisations like the WTO, the IMF and the OECD. The WTO liberalisation ethos and the IMF 'open market system' meant that the developing countries must comply to benefit economically from the industrialised world.

Academics, lawyers and economists view the popularity of 'free trade' as fundamentally challenging or threatening to today's international trade order ${ }^{2}$. Great thinkers such as Karl Marx, Thomas Jefferson and John S. Mill had no doubt that in time to come, all countries of the earth would be bullied into accepting western institutions and values, although Gray argues that the inclination to western institutions and values is only a prelude to universal civilisation. ${ }^{3} \mathrm{He}$ further argues that liberal thought and practice was introduced by the United

\footnotetext{
*LLB (Hons), Barrister \& Solicitor Supreme Court of Nigeria, LLM (Lond), Ph.D. (Law), University of London, UK. Email: isaacigwe@ hotmail.com.

${ }^{1}$ See Polanyi (1994) at 140.

${ }^{2}$ See generally- Bhagwati (1993); Hudec (1990).

${ }^{3}$ See Gray (1998).
} 
States. ${ }^{4}$ Transnational corporations employ liberal principles and try to force free markets onto every nation of the world. Their ultimate objective is to encourage policies to combine various economies into units of a world free market system. ${ }^{5}$ Gray argues that 'this is a utopia that can never be realised; its pursuit has already produced social displacement, economic and political instability on a large scale'. 6 The question now is what is the actual intent of this global free trade agenda and how has it reflected on the contemporary market interaction between developed and developing economies; is it likely to increase the economic conflict between the North and the South?

This writing will look at these questions by considering first, the classical and intellectual origins of free trade, particularly the intellectual contributions of erudite scholars such as Adam Smith and David Ricardo. The paper will also investigate the WTO context of free trade and fair trade, and will juxtapose it with the developing countries' position. The treatise will use this to articulate the trade liberalisation debate and the perversion of free trade by the powerful against the weak through protectionism. The writing will explore Regional Trade Agreements (RTA) as a collaborative strengthening mechanism for developing countries markets in the light of developed countries market dominance. Finally it will advocate for a more subtle legal and institutional approach and argue for a mutually competitive interplay or formation of rules that are within the international trade system.

\section{Classical Theory of Free Trade}

A new, industrialist government regime backed up by an elegant scholarly sect, eroded the era of mercantilism ${ }^{8}$ and brought in considerable economic freedom. It reached its peak when Britain's Corn Laws were repealed in $1846 .{ }^{9}$ The impact of the widely accepted 'classical school' led to the immediate modification of economic activities in some advanced worlds. ${ }^{10}$ Among the intellectual advocates of free trade, none are more globally accredited than Adam Smith and David Ricardo. Adam Smith's Wealth of Nations could be said to be the starting point for any study of free trade in Britain. ${ }^{11}$ What is free trade becomes an issue of rhetoric. It simply means the right of passage of goods between nations without impediments and attachments such as tariffs or taxes.

\footnotetext{
${ }^{4}$ See Gray (1995).

${ }^{5}$ See Schumpeter (1928) at 368.

${ }^{6}$ Ibid.

${ }^{7}$ See Economists (1994) at 32.

${ }^{8}$ Mercantilism is economic nationalism for the purpose of building a wealthy and powerful state. Adam Smith formed the "mercantile system" to describe the system of political economy that sought to enrich the country by restraining imports and discouraging exports. See LaHaye (19992004).

${ }^{9}$ The Corn Laws was in force between 1815 and 1846 when import tariffs were designed to support and protect domestic British corn prices against competition from less expensive foreign - grain imports. See Schonhardt-Bailey (2006).

${ }^{10}$ See Keynes (1936).

${ }^{11}$ See McCord (1970).
} 
Adam Smith's economic free market theory was intended to enhance the world standard of living. It may be that the same spirit motivated the GATT 1947 preamble which provided that 'the contracting parties shall commit themselves to the objectives of [...] raising standards of living, ensuring full employment and a large and steadily growing volume of real income and effective demand, developing the full use of the resources of the world and expanding the production and exchange of goods'. ${ }^{12}$ The language of the GATT preamble simply states the setting up of rules and policies to engender trade liberalisation by substantially eliminating trade restrictions such as tariffs and other discriminatory practices. The GATT is a treaty organisation whose role is to expedite international trade with its basic principles of liberalisation, stability and transparency or more generally the principles of non-discrimination and reciprocity. ${ }^{13}$

The World Trade Organisation (WTO) which superseded the GATT has in recent times clearly shown evidence of being a free trade crusader. After the Uruguay round agreements, Renato Ruggiero, the WTO's director general stated as follows:

"We live in a world which is already launched on a path towards global free trade. It is a process which cannot be reversed or rolled back without unimaginable costs to our future growth and our future progress. The challenge now is to come to grips with a world of free trade and deeper integration, and to realise its immense benefits. It is a choice between building a global architecture which is open, universal and rules-based, or living in a system which is anarchic in the most literal sense of the word. If one chapter of world economic history ended with the technological revolution of the last decade and with the mammoth liberalising efforts symbolised by the Uruguay Round, another is about to begin. How it is written will depend on the decisions we make in coming months and years.",14

Ruggiero further in his address likened the WTO to the 'global architecture' which will prepare the structural background for the realisation of free trade and said:

"Fortunately some of the global answers are already at hand. The WTO was the first major international institution to be created in the post-Cold War, post Uruguay Round era. This is significant because I believe the WTO offers a promise of the kind of global architecture we need in the coming decades. It grew out of bottom-up pressure for free trade and deeper integration." 15

Though the WTO Agreement has not expressly included free trade as one of its objectives, it has become an intrinsic laudable objective of the institution.

\footnotetext{
${ }^{12}$ See also GATT (1947).

${ }^{13}$ Ibid.

${ }^{14}$ See Ruggiero (1996).

${ }^{15}$ Ibid.
} 
Free trade assists in the elimination of poverty, ${ }^{16}$ and non restriction of trade enables developing countries to meet up with developed countries while enhanced economic growth assists in poverty elimination. ${ }^{17}$ In line with this, Mike Moore (former WTO Director General) said:

"this report confirms that although trade alone may not be enough to redirect poverty, it is essential if poor people are to have any hope of a brighter future. For example, 30 years ago, South Korea was as poor as Ghana. Today, thanks to trade led growth, it is as rich as Portugal", 18

Today, Adam Smith's insights in Wealth of Nations on free trade still echo, though his influence waned over the generations with the emergence of free market capitalism. Capitalism was criticised heavily in the $19^{\text {th }}$ century for misusing trade practices. Notwithstanding the Marxist view that capitalism meant exploitation of the labour force, or monopoly of the market, Karl Marx maintained that:

\section{"[...] there will always be class which exploits and a class which is exploited.",19}

\section{Adam Smith}

Smith was known for his classic contribution to capitalist economics. He supported arguments based on the theory that the less governments interfere with trade, the more wealth the nation will accumulate. ${ }^{20}$ Although Smith did recognise the necessity of imposing some tariffs, he potentially argued against attachment of restrictions in global trade. In his view of the operation of the economic world, he argued that everybody competes to be rich, 'intending only his own gain', but to this end he must exchange what he owns or produces with others who sufficiently value what he has to offer; in this way by division of labour and a free market, public interest is advanced. ${ }^{21}$

Smith in his illustration visualised an 'invisible hand' operating as the tool of a gracious god who moves man's self-centredness to maintain a global status quo of happiness. The way to enrichment requires interdependence with others and in the process others are bound to benefit from it. He argued that society must have a moral conscience to prevent stealing and deceit before the invisible hand mechanism could work efficiently. He conceded that there was no harm in the poor emulating the rich but it was government's responsibility to defend the rich against the poor. From the foregoing argument, the importance of Smith's 'moral

\footnotetext{
${ }^{16}$ See WTO (2000b).

${ }^{17}$ Ibid.

${ }^{18}$ See WTO (2000a).

${ }^{19}$ See Marx (1976) at 463.

${ }^{20}$ These arguments have been repeated in recent years in the United States in regard to such Japanese imports as automobiles and in the context of debates over the North American Free Trade Agreement (NAFTA) and the General Agreement on Tariffs and Trade (GATT).

${ }^{21}$ See Smith (1776) [1976].
} 
norms' cannot be over emphasised. Thus for a trading system to work properly, agreement must be actionable, the parties concerned should have adequate information readily available to them, and it must be guided by the rule of law.

The industrialised nations' attitude towards the developing world is inseparable from capitalism. Smith articulated this when he began the thesis of a business empire that retains the inconsistency of "private enrichment and public interest'. ${ }^{22}$ The capitalist intends only his own self-enrichment but is 'led by an invisible hand to promote an end which was no part of his intention'. ${ }^{23}$ Hardt and Negri, agreeing with Smith, argue that the 'invisible hand' of the market must be understood as a product of political economy itself which is directed toward constructing the conditions of market autonomy. ${ }^{24}$

In the $18^{\text {th }}$ century economics was considered a branch of philosophy and Smith's Wealth of Nations was an exploration of the human psyche. ${ }^{25}$ Smith advocated that to progress, economic systems should not rely on principles of living and acting for the interest of others, but on the self-interested motivation of individuals. He argued that 'the collective pursuit of self-interest, if done in the right way, could generate enormous collective wealth and it was that which should hold societies together'. ${ }^{26}$ He further argued that the two best ways of generating collective wealth, were to respect the allocative efficiency of the free market and to have a high degree of specialisation in the workforce.

In Smith's view, in a free market, producers are motivated by virtuous selfinterest that sees them strive to make the most desirable goods at the most competitive prices - led by 'an invisible hand'. ${ }^{27}$ Smith argues that free trade would encourage efficient distribution of resources, raise productivity and enhance everybody's purchasing power. ${ }^{28}$ This would be termed the foundation of free trade based on the principles of mutual gains from trading with one another, exchanging goods and benefiting from specialised lines of production.

\section{David Ricardo}

David Ricardo was a strong advocate of free trade, but moved beyond Smith's thesis in 1817 by propounding the theory of 'Comparative Advantage'. ${ }^{29}$ Essentially, the theory held that when one country produces goods more efficiently and cheaply than another it is advantageous for both for the more efficient one to specialise. $^{30}$

Ricardian comparative advantage applies internally in trading nations, not externally between them. It denotes that in a system of unrestricted free trade, the

\footnotetext{
${ }^{22}$ Ibid, at.456.

${ }^{23}$ Ibid.

${ }^{24}$ See Hardt \& Negri (2001).

${ }^{25}$ See Buckman (2005).

${ }^{26}$ Ibid.

${ }^{27}$ See s Rohmann (2002) at 362.

${ }^{28}$ See Kennedy (1988) at 462.

${ }^{29}$ See Ricardo (1817). See also De Vivo (1987).

${ }^{30}$ See Ricardo 1817).
} 
allocation of resources will be maximally productive within each trading nation, and thereby, by inference, throughout the world. Insofar as the world becomes a single market, efficiency and productivity in every country will be maximised. ${ }^{31}$ Ricardo's theories were influenced by his time. They were developed when Britain was suffering from high food prices, apparently due to the Napoleonic Wars, and Ricardo suggested that the country could lower this cost by specialising in manufacturing and importing all its food. ${ }^{32}$ Ricardo does not follow Smith's investigation of human passions or the desire to improve material wellbeing. Ricardo's approaches to free trade are from an economic angle and focus on the advantages deriving from the international division of labour.

Smith's theory of specialisation poses that nations can mutually benefit from trade by specialising in the production of goods when countries differ in their ability to produce them. Instead, Ricardo went further using Portugal and England to demonstrate that countries can still gain from specialisation despite one of the countries possessing absolute advantage in producing two products. Ricardo explained that if the yardstick was the difference in the costs of production between the two goods, they could still specialise in manufacturing the one with the lowest cost. It is similar to the abolition ideals of the Corn Laws which encouraged protectionist trade practices. ${ }^{33}$

This brings us to Ricardo's opportunity cost in terms of forgone alternative in determining the convenience of trade. ${ }^{34}$ For a more compendious reading, Ricardo's explanation of the concept of comparative advantage would play a vital role here:

"The quantity of wine which she (Portugal) shall give in exchange for the cloth of England is not determined by the respective quantities of labour devoted to the production of each, as it would be if both commodities were manufactured in England, or both in Portugal. England may be also circumstanced that to produce the cloth may require the labour of 100 men for one year; and if she attempted to make the wine it may require the labour of 120 men for the same time. England would therefore find it her interest to import wine, and to purchase it by the exportation of cloth. To produce the wine in Portugal might require only the labour of 80 men for one year, and to produce the cloth in the same country might require the labour of 90 men for the same time. It would therefore be advantageous for her to export wine in exchange for cloth. This exchange might even take place notwithstanding that

\footnotetext{
${ }^{31}$ Ibid, at 155 .

${ }^{32}$ See Backhouse (2002) at $137-139$.

${ }^{33}$ Ricardo favoured an end to the Corn Laws, arguing that Britain ought to import corn from countries better equipped to produce it at lower cost. He hated the rising rents he attributed to the laws, since they came in his view, at the expense of the driving force of the economy - profits. Twenty-three years after his death, the laws were repealed and Ricardo's international free trade agenda became one with British public policy. Ricardo had provided an answer to Britain's longterm growth problems, and Britain became the 'workshop of the world', importing most of its food and 'outsourcing' most of its agricultural employment. Ricardo's ideas became the 'foundation of all nineteenth century free trade doctrine', see Blaug (1986) at 201.

${ }^{34}$ See the general discussion in Ekelund \& Hebert (1997).
} 
the commodity imported by Portugal could be produced there with less labour than in England. Though she could make the cloth with the labour of 90 men, she would import it from a country where it required the labour of 100 men to produce it, because it would be advantageous to her rather than employ her capital in the production of wine, for which she would obtain more cloth from England, than she could produce by diverting a portion of her capital from the cultivation of wines to the manufacture of cloth. "35

In Ricardo's discourse, it is clear that though every nation possesses a 'comparative advantage' in the goods they produce, no two countries can arrive at the same comparative costs. In order to show how international free trade could benefit every country and maximise world output, Ricardo used a two-countries, two products and one-factor of production analysis. By the same token, he posited the assumption of the international immobility of capital and labour. However, Ricardo's comparative advantage had been underpinned by several assumptions of the day. James Mill $^{36}$ and Robert Torrens ${ }^{37}$ touched on the issue of comparative advantage or issues relating to it before Ricardo but were inclined to criticise Ricardo's account as limited in scope or inaccurate. ${ }^{38}$ A shift in economic thought occurred in this divide when other economists defended Ricardo's theory. ${ }^{39}$ The defence here may not be water-tight in the ongoing academic debate, as it seems doubtful that these great economists could turn around their stand on Ricardo being the originator of this idea.

According to Ricardo's theory, factors of production cannot cross national boundaries and once a country holds a competitive edge in the production of a product, it will never lose it. In the nineteenth century, this argument was valid because even though goods had become more mobile, global capital had not. Ricardo's assertion will be true so long as capital is not internationally mobile. The implication of universal capital movement is to undermine the Ricardian model of 'comparative advantage'. Ironically, that is the foundation of unmanageable world free trade. Michael Porter noted that 'the standard theory of comparative advantage assumes that there are no economies of scale, that technologies everywhere are identical, that products are undifferentiated, and that the pool of national factors is fixed. The theory also assumes that factors, such as skilled labour and capital, do not move among nations. All these assumptions bear little relation, in most industries to actual competition. ${ }^{40}$

Conversely, today, capital can move very freely around the world and factors of production can easily move between countries. If Ricardo's writings were to be in this contemporary era of transnational corporations and upsurge of foreign direct investments, his assumptions would have been otherwise. ${ }^{41}$ This simply

\footnotetext{
${ }^{35}$ See Ricardo (1817) at Chapter VII.

${ }^{36}$ See Mill (1848) at 21.

${ }^{37}$ See Torrens (1844).

${ }^{38}$ See Rothbard (1995) at 96-98.

${ }^{39}$ Ibid.

${ }^{40}$ See Porter (1990) at 12 and Dornbusch, Fischer \&Samuelson (1977) at 823-839.

${ }^{41}$ Both in pursuit of transnational corporations and foreign direct investment both capital and labour would move freely across the borders of nations.
} 
means that comparative advantage has been replaced by competitive advantage and has thus relaxed Ricardo's theory.

\section{Regional Trade Agreements (RTAs)}

Some controversies have dogged the WTO since its inception and other problems continue to develop as the organisation evolves. Growing discontent targeted the GATT in the first decade of the WTO. The Uruguay round is perceived to have failed developing countries with the collapse of two of the five WTO ministerial conferences. Uncertainties about the organisation have grown to such a crescendo that countries resorted to a proliferation of bilateral and regional trade agreements that puts the role of WTO in doubt as it undermines the position of the Developing Countries (DCs) and the Least Developing Countries (LDCs). The emergence of RTAs in the WTO started with the GATT 1947 under Article XXIV. The Uruguay Round negotiation provided the legal framework for RTAs in the area of trade in goods, GATs Article V, the Enabling Clause for the mutual reduction of tariffs on trade in goods among developing countries. The WTO fourth ministerial conference in Doha discovered that RTAs would be of importance in promoting trade liberalisation and enhancing economic development and encourage a mutual coexistence between the multilateral and regional processes. Thus the verification of RTAs compliance in the WTO was entrusted to the Committee on Regional Trade Agreements (CRTAs) ${ }^{42}$ which has met some challenges. ${ }^{43}$ The Doha Development Agenda, created to correct the problems of the DCs, has proven remarkably ambitious with limited success. ${ }^{44}$ Regional Trade Agreements (RTAs) are traditionally created for liberalisation of trade among members but later includes services. The Chile, Singapore Free Trade Agreements (FTAs) with the USA, and the North American Free Trade Agreements (NAFTA), are examples of RTAs that allow professionals into member states to promote trade in services.

It is worthy of note that NAFTA began with unilateral track and bilateral liberalisation between the USA, Canada and Mexico in 1980 which in 1989 culminated in the Canada- USA Free Trade Agreement (CUFTA) and in 1992, NAFTA. By 1994, NAFTA was deemed a model free trade agreement, the most comprehensive free trade treaty of its kind with a combination of first and third world countries that comprises about 360 million people, making it the largest free trade zone. ${ }^{45}$ The rationale for NAFTA ranges from such motives such as 'lock in Mexican liberalising reforms and the promotion of growth and industrialisation south of the border to prevent inflow of illegal immigrants from Mexico to USA. Moreover, the motive has been linked to market access to Latin America as well as

\footnotetext{
${ }^{42}$ WTO CRTAs terms of reference can be located in WT/L/127.

${ }^{43}$ There has been complexities of problems ranging from political or legal, most of which inherited from the institution of the GATT; interpreted of WTO rules against the RTAs or institutional problems as a result of the absence of WTO rules (rules of origin) or from discrepancies between WTO rules and RTAs rules.

${ }^{44}$ See Froman (2015). For further reading see Lester (2016).

${ }^{45}$ See Dunkley (2000) at 89.
} 
the US agenda for western economic leadership. ${ }^{46}$ However critics perceive NAFTA as a leading force of the new world order that emerged to privatise and de-regulate economies, largely shifting power to the multinational companies, tearing apart welfare states and weakening democracy. ${ }^{47}$ The controversy surrounding NAFTA led to the advice that the Clinton government should abandon it. ${ }^{48}$ Nonetheless, the NAFTA still remains the most comprehensive free trade treaty ever signed.

RTAs are embraced by many WTO members as trade policy instrument and complementary to Most Favoured Nations (MFN). The Committee on Regional Trade Agreements (CRTA) for the multilateral Conference was forced by WTO members in the $10^{\text {th }}$ Ministerial Conference in Nairobi in 2015 to continue looking into the outcome of RTAs and as of 1 May 2018, 287 RTAs were operational. ${ }^{49}$

This in turn would benefit the multilateral trading system (MTS) by enabling unforced openness that could balance competitive liberalisation in global trade relations. No doubt, the proliferation of RTAs among WTO members and MTS could mean a challenge or an opportunity. It could become an opportunity for the DCs to push for implementation of domestic reforms into the WTO liberalisation agenda to promote their integration in the world economy. Nonetheless, it could become a challenge when it undermines the transparency and predictability in global trade relations which is at par with multilateral trade objectives. Traditionally, the formation of RTAs happens between geographically close countries with existing formed trading patterns. The NAFTA countries, the European Community (EC), Australia and New Zealand, EFTA and CEFTA are good examples. ${ }^{50}$ Other regional patterns may be formed as a result of regional proximity, such as South-east Asian countries' participation in ASEAN, western Hemisphere partners of CARICOM, the CACM, the MERCOSUR ${ }^{51}$ or the subSaharan African groups such as CEMAC or $\mathrm{SACU}^{52}$ are all good examples. The existing agreements may be supplemented towards expansion, in many cases beyond neighbouring countries and entering into free trade agreements (FTAs). India has signed the South Asian Free Trade Agreement (SAFTA) which includes such countries as India, Bangladesh, Sri-Lanka, Thailand and Myanmar. Also, India has signed an agreement with the Southern Common Market (MERCOSUR) as a prelude to Free Trade Areas (FTA) and concluded an FTA with Chile and SACU in 2007. In line with this, sub-Saharan Africa has engaged in initiatives such as WAEMU, CEMAC, COMESA and the $\mathrm{SADC}^{53}$, created to promote free

\footnotetext{
${ }^{46}$ See Clark (1994); GAO (1993).

${ }^{47}$ NAFTA on free trade views, see Hufbauer \& Schott (1992). For critiques, see Cohen (1994). See WTO (2009).

${ }^{48}$ See Dryden (1995) at 381.

${ }^{49}$ See WTO (2017).

${ }^{50}$ EFTA: European Free Trade Association; CEFTA: Central European Free Trade Agreement.

${ }^{51}$ CARICOM: Caribbean Community and Common Market; CACM: Central American Common Market; MERCOSUR: Southern Common Market.

${ }^{52}$ CEMAC: Economic and Monetary Community of Central Africa; SACU: Southern African Customs Union

${ }^{53}$ WAEMU: West African Economic and Monetary Union; COMESA: Common Market for Eastern and Southern Africa; SADC: Southern African Development Community.
} 
trade areas or customs unions. Regional integration comes with such problems as complex webs of overlapping membership but it is nonetheless a vital alternative to the Uruguay Round multilateral free trade arrangement. Indeed, the Economic Partnership Agreements (EPAs) between the EU and the African Caribbean and Pacific group of countries (ACP) and their existing regional groupings is a move in the right direction. The wide spread of RTAs was encouraged for access to larger markets at the regional or bilateral level since there is unwillingness among WTO DCs members to multilaterally liberalise their markets further. RTAs can be seen as a defensive mechanism for smaller countries maintaining market access options without a liberalisation driven by MFN.

RTAs can also be a mechanism for promoting stronger economic integration, especially in connection with multilateral issues such as investment, competition, environment and labour standards. They enable countries to engage in discriminatory liberalisation in order to gain from trade in products with which they cannot ordinarily compete internationally. Membership in RTA is believed to enhance getting foreign direct investment among low labour cost countries that has preferential access to a larger developed markets. The inflow of Foreign Direct Investment (FDI) into Mexico was at the beginning of its membership to NAFTA. Instead of DCs continuing with a General System of Preferences (GSP) programme, they can sign into RTAs with developed countries and obtain access to their markets, which in effect will draw foreign investment into DCs. This strategy will present a dual locking function to RTAs; locking out competition and locking in foreign investment. However, some developed countries' membership of RTAs may be driven by political security concerns, new geographical alliances or cementing diplomatic ties with other countries. In such a case, the economic rationale for signing into RTAs will be undermined or depreciated. RTAs are dynamics for economies of scale, competition and attraction of FDI. Liberalisation through RTAs may appear to be second-best to a multilateral system, but could nonetheless be the best option available for opposing a regime of multilateral liberalisation. Such a regional agreement could create harmonized tariff treatment on imports of all goods to avoid the undermining of preferential margins such as rules of origin that makes international trade more complex and costly. ${ }^{54}$

Ordinarily, there are four notable likely avenues of trade liberalisation: unilateral (one country alone removing protective barriers), bilateral (two countries negotiating mutual protection reductions), regional (countries within a region developing liberalisation arrangements), and multilateral (universal negotiations for liberalisation and trading rules) trade liberalisation. However, free traders are concerned with GATT and RTAs because their trade negotiations take time, resources and as well put political agreements of the bodies at risk. In order to do away with 'unfair' trade practices which free traders such as Bhagwati criticised ${ }^{55}$, regional and multilateral trade principles for reciprocal liberalisation had been proposed by governments and international bodies to ensure negotiation compromise among members. ${ }^{56}$

\footnotetext{
${ }^{54}$ See UNCTAD (2011).

${ }^{55}$ See Bhagwati (1989) at 125.

${ }^{56}$ See Bhagwati (1994).
} 
Unilateralism or 'liberalism from below' is an ideal principle against the alternative slow track policy of reciprocity or 'liberalism from above'. This means the use of intergovernmental negotiations to secure trade liberalisation, which are most often politicised, time consuming and difficult. Trade negotiators' interests are centred on a power game as against economic benefits. If other parties engage in 'unfair trade' or not making enough concessions on market access, the game of reciprocity invokes threats of retaliation, whereas unilateral liberalisation takes a direct route to freer trade, avoiding reciprocity, government failure or retaliation. The ideal step will be a combination of unilateralism and multilateralism to strengthen private property rights in international negotiations. The combination of unilateralism and multilateralism will advance trade and liberalisation of investment as long as there is no discrimination against third parties.

The RTAs should be seen as a stepping stone to multilateralism and global free trade. This writing advocates 'more open regionalism' for the DCs as a means whereby the DCs RTAs would progressively embrace more and more countries in a manner similar to the development of CUFTA into NAFTA and the possibility of it becoming the free trade area of the DCs. The DCs engagement into RTAs will be subject to a comprehensive service agreement such as: national treatment; right of investment and establishment; market access for service professionals including the right to cross-border service sales; transparency of government regulations and harmonisation of professional service standards. ${ }^{57}$ Regional Economic Communities (RECs) of the DCs though will hamper their participation in the WTO, would facilitate regional co-operation and coordination among DCs and create synergies. Examples of such regional integration could be seen in Mauritius and Zambia. Both belong to two regional communities of common market for Eastern and Southern Africa (COMESA) and the Southern Africa Development Community (SADC). The consolidation of RTAs among the DCs with non-contiguous countries will help to combat the problem of multilateral liberalisation in a manner similar to the development of CUFTA into the NAFTA. Some literature has suggested that regional economic integration such as the NAFTA, EU, MERCOSUR, and the organisation of Asia-pacific Economic Cooperation (APEC) could encourage protectionism or erode the multilateral system created at the end of World War II; whereas others argue that regional economic institutions will enhance economic openness and promote a multilateral system. These debates have not been settled among researchers or economists. ${ }^{58}$ Nonetheless, the combination of the RTAs involving the DCs as a front against the multilateral system of the WTO will position them better in the global economic system. The proliferation of RTAs among the DCs without a symmetrical interest and common purpose will dilute the strength in the DCs economic cooperation and coordination. The ideal RTAs will constitute the conglomeration of all the RTAs that currently operate to unify together with a common trade agenda in order to serve the purpose of economic development for all DCs and LDCs.

\footnotetext{
${ }^{57}$ See Dunkley (2000) at 91-92.

${ }^{58}$ See Cohen (1997) at 50-76. See also Duina (2016).
} 


\section{Free Trade and Sustainable Development}

Liberalisation of trade and reformation of the WTO could be perceived as the pillars of lasting economic growth, which could lead to the reduction of global poverty. The WTO preamble to its agreement enshrined 'sustainable development' as the ethos of its institution. Accordingly, this was demonstrated at the Doha ministerial conference of November 2001 which formulated a framework of trade liberalisation steps basically envisaged to result in a 'development round' of discussions with an emphasis on responding to developing countries' needs. ${ }^{59}$

The short-lived optimism of the Doha Declaration on development was followed by the failure of the WTO Cancun meeting in 2003, caused by the debacle concerning the 'Singapore Issues ${ }^{60}$ and the disagreement between United States and European Union over trade liberalisation within agriculture. These incidents drew suspicion from the developing countries members over the readiness of the developed world to step forward ahead of the rhetoric of their international trade promises ${ }^{61}$. The failure of Cancun Ministerial Meeting attracted debates between the member states of the WTO based on economic globalisation and focussed on the international debate on trade and development. These debates were divisive; on one hand further strengthening of global trade would be visualised as an important part of 'sustainable development ${ }^{\prime 2}$ on the other as destructive, especially as it related to the interests of poor countries. ${ }^{63}$

Nonetheless, most member states favour strengthening WTO trade rules although with apprehension that they might not be sustainable, could be inappropriately established or poorly implemented and defeat their aims. ${ }^{64}$ Needs varies from one country to another. However, the definition of sustainable development came out of the report from the World Commission on Environment and Development as 'development which meets the needs of the present without compromising the ability of future generations to meet their own needs' ${ }^{65}$ In keeping with this definition, the Johannesburg 2002 World Summit on Sustainable Development stated that 'these agreements cover both present needs and key factors in the ability to meet future ones'. Accordingly, one of the essential

\footnotetext{
${ }^{59}$ WTO (2001).

${ }^{60}$ The "Singapore issues" is a term which came after the Singapore Ministerial Conference in 1996 where Ministers from WTO Member-countries decided to set up four working groups namely investment protection, competition policy, transparency in government procurement and trade facilitation. There was a split between developed and developing economies which led to no conclusion on these issues even when they were revisited during the Cancun, Mexico Ministerial Conference in 2003, see Stiglitz \& Charlton (2005).

${ }^{61}$ See Oxfam (2000) argues that "Agriculture is the key to unlocking the Doha development agenda, and without constructive steps on this issue, the broader negotiations cannot really restart." Cited by Stiglitz \& Charlton, "A Development Round of Trade Negotiations in the Aftermath of Cancun." A report for the Commonwealth Secretariat, Published by Commonwealth Secretariat United Kingdom, 2004, note 23, p. 17.

${ }^{62}$ WTO (2003).

${ }^{63}$ See Khor (2003).

${ }^{64}$ See. Hoekman, Mattoo \& English (2002).

${ }^{65}$ The report of the World Commission on Environment and Development, (WCED or Brundtland Commission), 1987.
} 
objectives of Millennium Development Goals (MDGs) is to halve between 1990 and 2015 the proportion of people living in abject poverty on incomes less than one dollar a day. ${ }^{66}$ It is now 2018, 3years after the MDGs target, and the right question now is, has the goals been achieved. The MDGs 2001 targeted halve issues on eight key areas - poverty, education, gender equality, child mortality, maternal health, disease, the environment and global partnership. Records show that although significant improvement has been made in achieving some goals, it is not completely a success. ${ }^{67}$

The David and Kraay's free trade analysis concluded that an open market place is a necessary prerequisite for economic growth and poverty reduction. ${ }^{68}$ Thus OECD says 'more open and outward orientated economies consistently outperform countries with restrictive trade and foreign investment regimes' ${ }^{69}$ Additionally, the IMF says 'policies towards foreign trade are among the more important factors promoting economic growth and convergence in emerging countries'. ${ }^{70}$ The IMF further argues that

"globalisation influences economic growth and leads to greater incomes and that the countries that practice restrictive policies do not benefit; while the countries that achieve greater wealth are the ones that practice globalisation and committed to its principles", 71

These views led to their report of 2002 titled 'Globalisation, Growth and Poverty' which supported Dollar and Kraay's discoveries and arrangements and therefore concluded that 'the more globalised countries have made very significant gains in basic education while the less globalised had made less progress and now lag behind in primary attainment' ${ }^{72}$ The economic history of some countries has confounded Dollar and Kraay's analysis. The high economic growth of China in the late 1970s was not because of the reduction of its trade impediments which was left until second half of the 1980 s. $^{73}$ In the same vein, India did not undertake substantial trade reform until 1991-93 but its economic growth rate started to increase significantly in the early $1980 \mathrm{~s}^{74}$ Argentina in the early $20^{\text {th }}$ century before the Great Depression had a very strong economic growth rate without engaging in trade liberalisation, but followed import substitution to attain industrial self-sufficiency. ${ }^{75}$ Conversely, Vietnam experienced economic growth take-off in the mid-1980s when it cut its tariffs, but Haiti which liberalised its trade barriers in the mid-1990s experienced no pick-up in economic growth. ${ }^{76}$ At this

\footnotetext{
${ }^{66}$ See George \& Kirkpatrick (2004) at 441-469.

${ }^{67}$ See McArthur \& Rasmussen (2018).

${ }^{68}$ See Dollar \& Kraay (2001).

${ }^{69}$ See OECD (1998) at 36.

${ }^{70}$ See IMF (1997) at 84.

${ }^{71}$ See IMF (2000). See also Woodin \& Lucas (2004) at 17.

${ }^{72}$ See Dollar \& Kraay (2002) at 35.

${ }^{73}$ See Malhotra (2003) at 31.

${ }^{74}$ Ibid.

${ }^{75}$ See Beattie (2009).

${ }^{76}$ See Malhotra (2003) at 28.
} 
point, we can say that there is no uniform factor that leads to economic growth. The United Nations Development Programme in 2003 concluded that there is 'no systemic relationship between countries' average levels of tariffs and non-tariff barriers and their subsequent economic growth.'

WTO, World Bank, IMF policies are formed by the same interest stake holders (the hegemons) and their policies have underlining regressive economic agenda against the DCs. It will be oblivious to believe that the western world is genuinely interested in making the DCs economy to enjoy rapid growth. The policies are formulated to subjugate the DCs into perpetual dependants of developed country's assistance. Thomas Hobbes stated that man's natural tendency is violence, to rule, to lead and overpower others unless there is a law to check their brutishness. ${ }^{77}$ Free trade is absolutely free movement of goods from developed countries to developing countries, but not absolutely free movement of goods from developing countries to developed countries where barriers and tariffs are impediments to free flow of goods. In every policy of the developed countries, there is a sublime agenda to impoverish the poor like the recent dumping of toxic and substandard goods from China to African countries. ${ }^{78}$ There is no restriction of trade from the countries that are trying to endanger the lives of other countries all in the name of free trade. The actual reason why the WTO, World Bank and the IMF opined that free trade leads to rapid economic growth is to enable the Transnational Corporations (TNCs) who are part and parcel of the International financial institutions to have uninterrupted exit to push their manufactured goods and markets to the rest of the world. Otherwise, they will experience market glut to the extent that their companies can cease to exist.

The merits of free trade, a doctrine that touches on the basis of WTO instrument is the logic of fundamental virtuous of universal reciprocity that has profound moral foundation. ${ }^{79}$ Suffice to say that every country has a duty to protect itself economically, but the WTO MFN and Reciprocity principles must be observed. Most-Favoured Nations (MFN) Status-essentially states that the best treatment you grant to one of your trading partners should be accorded to all. This was arrived at as a matter of good governance, and represents 'centre of operations' of the WTO. ${ }^{80}$ But the concept predates the creation of nation-states.

\footnotetext{
${ }^{77}$ See Hobbes [1651] at 266.

${ }^{78}$ See Punch News (2017). See also McLaughlin (2012).

${ }^{79}$ See Moore (2003).

${ }^{80}$ The WTO in principle treats all members alike, whether rich or poor, strong or weak. At the centre of these rules is:

(1) The 'Most-Favoured Nations' (MFN), rules which prevents WTO members from discriminating between foreign goods or treating products from one WTO member as better than those from another one; and

(2) The 'National Treatment' (NT), rule which obliges governments to treat foreign and domestically - produced products equally.

MFN obligation is embodied in Article 1 of the GATT, Article II of the General Agreement on Trade in Services (GATS), and Article 4 of the Agreement on Trade-Related Aspects of Intellectual Property Rights (TRIPS), 1994. However, there are some exceptions allowed to MFN, but the agreement permits these exceptions under strict conditions. For example under GATT Article XXII countries within a region can set up a free trade agreement that does not apply to goods from outside
} 
What is good for an individual provides a principle of moral behaviour that extends beyond any one faith. It is the basis of civilised behaviour.

\section{Behind the Scenes of Global Free Trade}

One can arguably say that the truth behind the encouragement for global free trade is hinged on the creation of a western empire or hegemony though plausibly presented as an ideal framework for the poor economy of the developing nations, but in reality hidden by capitalist undertones to economically rule the entire world. The global free trade campaign is clandestinely geared towards long-term northern economic security.

There is basically no harm in a country protecting its economy. An unbalanced policy of asking the developing countries to open access to their raw materials without reciprocal obligation could be termed uncaring treatment of others for one's own selfish gains. This defies morality and acceptable ethical behaviour. It is apparent that the pursuit of self-gain echoed by Adam Smith ${ }^{81}$ or Albert Hirschman ${ }^{82}$, has underpinned the principles of reciprocity provided in the WTO policies to ensure sustainable development.

Free trade, which has been professed by many as the ideal system for balanced development in the 'two worlds', exists only in principle; the debacles of tariffs and subsidies in agriculture have not been properly addressed. Gordon Brown, then chancellor of Great Britain, once recommended "ending the hypocrisy of developed country protectionism" through the removal of tradedestabilising subsidies and like impediments to trade transactions. ${ }^{83}$ The Group of Seven (G7) has been criticised for not having done enough towards opening their markets for the inflow of African export products such as cotton and sugar. It has been blamed for the collapse of the WTO 2003 Cancun Summit because of its refusal to take away US and EU agricultural subsidies, making competition difficult for the poor countries whose agriculture is not subsidised. ${ }^{84}$

However, in the WTO July 2004 'framework ${ }^{, 85}$ for negotiations on reduction of subsidies and other trade impediments, ${ }^{86}$ the issue of subsidy reduction attracted an ongoing debate in Doha conference on removing the developed countries' domestic farm assistance programme to reduce trade obstructions and eliminate export subvention. ${ }^{87}$ In lieu of lowering of subsidies, United States representatives sought for more third world access for US finished products and services. ${ }^{88} \mathrm{By}$ implication, greater access to African markets will encourage developed countries

the group. Also, a country can raise barriers against products from specific countries that are considered to be traded unfairly.

${ }^{81}$ See Smith 1976 (1776).

${ }^{82}$ See Hirschman (1987).

${ }^{83}$ See Brown (2005).

${ }^{84}$ See Buckman (2005).

${ }^{85}$ See WTO (2004).

${ }^{86}$ See Fergusson (2004).

${ }^{87}$ See Hanrahan (2005).

${ }^{88}$ See Copson (2005). 
to dump their manufactured goods, which will ultimately discourage developing countries' infant industries or even put them out of production as they would face competitive prices from similar manufactured goods from the developed countries. ${ }^{89}$ Nonetheless, record has shown that since 2000 the United States has done more than other countries to remove trade barriers through a programme termed the African Growth and Opportunity Act (AGOA). This programme allowed 37 sub- Saharan African nations the duty-free access to America of a variety of products, among which 24 were authorised to export textiles and clothing. ${ }^{90}$

The underpinning factor could be the attachment of concessionary measures in return and the United Kingdom and European Community (though noted to have negotiated 'Economic Partnership Agreements of African Caribbean and Pacific countries') have not followed American footsteps despite professing the desire for development, economic growth and the eradication of poverty for these regions of the world. These unilateral actions by poor WTO members to improve their trade policy space ranging from structural adjustment loans and bilateral arrangements though not imposed or required for WTO membership are potentially subject to WTO rules and regulations which are imbalanced. ${ }^{91}$

\section{More Trade Liberalisation}

The vexed issue in trade policy is whether a greater flow of trade or liberalisation of trade would make the system fairer. The 'fair trade school' argues that greater access by developing countries to developed countries' markets would unequivocally make the developing countries wealthier. That is to say, that greater trade would reduce world poverty and inequality. On the other hand, the 'localisation school' argues that sustainability would come through less trade and national self-reliance. ${ }^{92}$

Oxfam one of the 'fair trade schools' in 2002 set in motion a campaign to 'Make Trade Fair' with a report in which it clearly argued that 'the increasing integration of developing countries into the global trading system offers the promise of more rapid progress towards poverty reduction and improved standards of living. ${ }^{93}$ The report stated that 'if Africa, East Asia, South Asia and Latin America were to increase their share of world export by 1 per cent 128 million people could be lifted out of poverty'. ${ }^{94}$ George Monbiot argues that, 'rich countries $[\ldots]$ would be required to pull down their barriers to trade. They would

\footnotetext{
${ }^{89}$ It is not clear whether this development would lead to reduction of the trade barrier sought by Tony Blair and Gordon Brown in Gleneagles July, 2005. But one thing is clear; the Summit did take action on specific reduction.

${ }^{90}$ See Fergusson \& Langton (2005).

${ }^{91}$ See Milner (2006) at 1409-1422; see also Milner \& Zgovu (2006) at 251-268.

${ }^{92}$ See Buckman (2005).

${ }^{93}$ Oxfam International (2002) at 239; Neil (2007).

${ }^{94}$ Oxfam International (2002) at 3.
} 
be permitted neither to subsidise their industries nor to impose tariffs or other restraints upon imports from poorer countries. ${ }^{, 95}$

There has been a shift in the argument that increasing liberalisation and market access would end the problems of poverty. On the contrary, it could worsen the situation especially trade liberalisation in important areas such as agriculture and textiles. ${ }^{96}$ A reasonable apprehension abounds that if developing countries had greater access to developed world markets, developed countries would demand greater access to low-income countries' markets in return. This would drastically affect the developing countries, especially their agricultural and manufacturing industries. As the majority of developing countries are heavily dependent on agricultural products, lifting restrictions to agricultural imports too soon could dislodge local populations. ${ }^{97}$

By and large, greater access to developed countries' markets by developing countries, especially the agricultural sector, would increase their dependency on food imports. Thus Action Aid said in reaction:

"Many developing country governments see increased access to developed Country markets as extremely important, but Action Aid is more cautious because of concerns that this could fuel an explosion of export - orientated agriculture in developing countries at the expanse of small - scale producers and the environment. This trend has been seen in Brazil with a rapid expansion in soybean production and in Indonesia and Malaysia in relation to oil palm production for export. Also, typically, produce from low-income farms is sold on local and national markets and so for small-scale farmers, increases in export markets are to a large extent irrelevant." 98

Opposed to the 'fair trade school' is the 'localisation school' which believes that true trade sustainability will only come through restricting trade to its bare essentials, and the regions and countries should become more self- reliant. Hines, the standard bearer of localisation as the new protectionism says, "we look to less trade [...] every effort should be made to meet requirements from local sources first, then nationally, then regionally, and only after that internationally. ${ }^{, 99}$

He encourages the use of tariffs to bring about localisation and advocates that all exporters need to re-orientate production towards more local markets. ${ }^{100}$ Hines' advocacy of localisation had been accepted by both the International Forum

\footnotetext{
${ }^{95}$ See Monbiot (2003) at 218; see also Fisher \& Ponniah (2001) at 76; Parris (1999) at IV., 'Trade for Development - Making the WTO Work for the Poor', World Vision, East Burwood (Australia), 1999, p. IV.

${ }^{96}$ See Wiesbort \& Baker (2002) at 1 . On the issue of trade liberalisation being part of the problems of developing countries trade system and not a solution to problems of growth and poverty see Christian Aid (2004).

${ }^{97}$ See Weisbrot \& Baker (2002) at 2.

${ }^{98}$ See Action Aid (2003) at 11.

${ }^{99}$ See Hines \& Lang (1993) at 128.

${ }^{100}$ See Hines (2000) at 65.
} 
on Globalisation ${ }^{101}$ and Friends of the Earth International. ${ }^{102}$ However, opposing localisation, Oxfam says that 'a retreat into isolationism would deprive the poor of the opportunities offered by trade', ${ }^{103}$ and that 'national sovereignty without a systematic strategy for poverty reduction is little more than a one-way street leading to self-sufficient misery'. ${ }^{104}$

The issue of more trade liberalisation, right from the failure of the WTO Seattle Ministerial Meeting in 1999, has been viewed as complicated. The unsuccessful result of Seattle provided a cause to review and rethink the ideal steps for trade procedure. ${ }^{105}$ Paradoxically, the views of both developing countries and academics on the subject-matter are ambivalent. On one hand, trade liberalisation has been advocated as necessary to economic expansion and development. However, the UNCTAD findings demonstrate that there is no automatic correlation between trade liberalisation and expansion. ${ }^{106}$ In another view, some developing countries have criticised trade liberalisation as the main source of their economic retardation, making them outcasts in the economic global arena. ${ }^{107}$

It has often been asserted by some scholars that liberalisation has benefited 'the world', that 'we are all gainers, there are no losers ${ }^{\text {, }}{ }^{108}$ This generalisation is untrue; some countries, especially the poorest, have gained virtually nothing. The truth is that only a few have experienced moderate growth in the last 20 years while the majority has suffered a reduction in living standards per capita income measurement. ${ }^{109}$ The question here is whether global free trade has been intended as a universal benefit or a social form of contemporary mercantilism, designed to dominate the South. ${ }^{110}$ Some like-minded scholars have associated free trade with colonialism and the perpetuation of economic inequalities. ${ }^{111}$ These assertions were informed by the international trade system pre-dating GATT which proposed a code creating a set of rules for an 'open international market ${ }^{112}$, but the syndrome of some western countries alternating protectionism with free trade has not been wiped out. ${ }^{113}$ The 'trade taxes' must be eradicated, before the developing world's export strength can be appreciated. Essentially, trade in agriculture for

\footnotetext{
${ }^{101}$ The International Forum on Globalisation (IFG), 'Alternative to Economic Globalisation: A Better World is Possible',2002, p.12, available at http://www.ifg.org 11/09/2018

${ }^{102}$ Friends of the Earth International (2000) at 8, 10. L, 'Towards Sustainable Economies: Challenging Neoliberal Economic Globalisation', 2003at 8, 10.

${ }^{103}$ See Watkins \& Fowler (2002) at 16.

${ }^{104}$ Ibid, at 24 .

${ }^{105}$ WTO Meeting held in Seattle Washington Nov/Dec. 1999 failed to launch proposed new 'Millennium Round' of global trade. 50,000 people took to the streets of Seattle in an unprecedented show of public protest against the talks. See Bhagirath (2003) at 15; Khor (2000) at 11-15.

${ }^{106}$ See UNCTAD (1999). See also Hatchard \& Perry-Kessaris (2003).

${ }^{107}$ Ibid.

${ }^{108}$ See Khor (2000).

${ }^{109}$ See UNDP (1999) at 31.

${ }^{110}$ See Lowenfeld (2002) at 9.

${ }^{111}$ See Gearey (2005) at 6.

${ }^{112}$ See Hudec (1987) at 8.

${ }^{113}$ See Gearey (2005).
} 
African countries cannot be overemphasised and they should be allowed to determine the rate of their liberalisation. ${ }^{114}$

Ironically, African agricultural markets are liberalized far and above their western trading counterparts. Liberalisation was imposed on African governments more than 20 years ago through the Structural Adjustment Programme (SAP) ${ }^{115}$, bilateral aid ${ }^{116}$ and trade measures to reduce manufacturers' subsidies and eliminate tariffs quickly as against the Uruguay Round principles. ${ }^{117}$ The policies of the Uruguay Round of trade agreements are imbalanced with a plethora of tariff and non-tariff measures for African exports and highly subsidised European and United States food products, mostly marketed below manufacturing price to outcompete African farmers in local and international markets. This will lead to impoverishment of rural Africa, urban migration, and the displacement of minority people. Trade liberalisation, if imposed on countries not yet ready, could lead to financial instability and debt, deteriorate balance of payments, cause poverty or result in economic recession.

A more realistic approach should be taken towards trade liberalisation. There should be no more hassles on third world to open their markets more. A slowdown approach should be adopted just as more time was given to the developed countries to hold a huge protection in agriculture, textiles and other industrial goods for the reason that they needed ample time to adapt. ${ }^{118}$ The developing nations should be allowed to determine when they are ready, free and amenable to strategise their financial choices, trade and investment policies in order to be able to decide on the rate and scope of liberalisation that would fit and/or benefit their ailing domestic industries and products. ${ }^{119}$ They should not be bullied into further opening up their markets; ${ }^{120}$ rather the developed world should find a solution to stop trade inequality.

On the other hand, the notion of embedded liberalism, articulated by John Ruggie $^{121}$ is a vital instrument to developing countries' economic prosperity. Embedded liberalism prevailed before the rise of the neo-liberal agenda; it entails

\footnotetext{
${ }^{114}$ See Igwe (2011).

${ }^{115}$ Structural adjustment is a policy of reducing government expenditures, lowering inflation, limiting imports, devaluing currency, and increasing economic efficiency, required by IMF of countries in debt as condition for debt restructuring.

${ }^{116}$ Bilateral aid is money given from one government to another. Bilateral aid may have strings which tie it to the country giving the money. This means for example, that if the UK government pays to build a dam, UK builders will do the work.

${ }^{117}$ See GATT (1994).

${ }^{118}$ See Lim (2005). On the same note, the Multi-Fibre Agreement (MFA) protection for developed countries' textiles and clothing industries is a case in point. More than three decades of protection from imports-and ten years advance warning that this protection would end on 1 January, 2005. Also Doha WTO Ministerial Conference, 9-13 November 2001, adopted on 14 November 2001. See www.wto.org S \& D - Article XXXVII of GATT, 1994. "The WTO agreements contain special provisions which give developing countries special rights. These special provisions include for example longer time period for implementing agreement and commitments or measures to increase trading opportunities for developing countries", https:/www.wto.org/english/tratope/dda e/dohaexplained_e.htm

${ }^{119}$ Igwe (2011).

${ }^{120}$ See Khor (2000).

${ }^{121}$ Ruggie (1982) at 379-415.
} 
embracing open international markets, with states retaining the right to engage in protectionism at national level. ${ }^{122}$ GATT/WTO mandated neo-liberalism seeks to distort policy options from the hands of states. The contention whether states can maintain equality and benefits for their citizens fades away and is overcome by the new occident market liberalisation ideology. The aftermath is a paradigm shift in the pursuit of western economic hegemony followed by uncertainty about the realisation of social justice, especially for the poor in the world. The market is held as a vehicle of growth and prosperity even if it is incompatible with the goals of equity and economic redistribution. ${ }^{123}$ International financial institutions such as the WTO, IMF and World Bank and the logic of 'globalisation' impose the path of the open market as a compelling principle, yet they maintain trade restrictions, protectionism and trade barriers. In tandem with the advancement and prevalence of the free market is the overshadowing and reduction of the power of states to development.

Critics and analysts have opined that the era of the state (a Golden Age from the end of World War II until the mid-1970s) which witnessed and recorded huge economic growth and a redistributive welfare state is decisively over. ${ }^{124}$ It has been alleged that the state can no more guarantee the basic standard of living of its citizens, instead individuals must look towards the chances and the uncertainties of global markets to fulfil their collective desires. ${ }^{125}$

Thus embedded liberalism is a tool to be considered as a response to the problems associated with the new global regime. This will articulate an unrestricted rebuilding exercise of the developing countries as a vehicle for lasting economic distribution through its private sectors.

\section{Conclusion}

Although the MDGs target was not met at the end of 2015, a significant achievement was reached by 2018 and more efforts are be intensified to improve global living standards. This writing has demonstrated a serious need for balanced fair trade rules that would work between the costs, benefits, interests and values of both developed and developing countries with appropriate flexibilities for the developing countries to implement development policies. The importance of the argument in this writing is the ability to manage trade properly to lead to sustainable development as an undirected restrictive trade system can be as bad as an undirected free trade system. ${ }^{126}$ This paper has not seen free trade system as a healthy option to revamp the low-income countries' economies considering the long term slide in the export prices of raw materials from DCs; short term protectionism becomes the best option for the DCs' economic growth. Thus, there

\footnotetext{
${ }^{122}$ See Igwe (2019).

${ }^{123}$ See Rittich (2001) at 95-108.

${ }^{124}$ Boyer \& Drache (1996).

${ }^{125}$ World Bank (1997).

${ }^{126}$ See Melamed (2002) at 1-7.
} 
should be a reintroduction of embedded liberalism in the global market to respond to global economic asymmetries.

\section{References}

Action Aid/Axione Aiuto (2003). 'The WTO Agreement and Agriculture.' Action Aid UK. https://www.actionaid.org.uk/sites/default/files/doc_lib/51_1_agreement_agri culture.pdf

Backhouse, R. E. (2002). The Penguin History of Economics. London: Penguin Books.

Beattie, A. (2009). 'Argentina: The Superpower that Never was.' Financial Times, May 23.

Bhagirath, L.D. (2003). The WTO and the Multilateral Trading System: Past, Present and Future. London: Zed Books.

Bhagwati, J. (1989). 'Is Free Trade Passé After All?' in Review of World Economics (Weltwirtschaftliches Archiv), 125(1):17-44.

Bhagwati, J. (1993). 'The World Trading System at Risk, Aggressive Unilateralism and Negotiating Issues' in the Global Trading System (eds. A. Deardoff \& R. Stern), Ann Arbor: University of Michigan Press.

Bhagwati, J., (1994). 'Fair Trade, Reciprocity and Harmonization,' in Analytical and Negotiating Issues in the Global Trading System (eds. A. Deardorf \& R. Stern), An Arbor: University of Michigan Press.

Blaug, M. (1986). Great Economists Before Keynes. NY: Cambridge University Press.

Boyer, R. \& D. Drache (eds.) (1996). States Against Markets: The Limits of Globalisation. London: Routledge.

Brown, G. (2005). 'Speech by the Rt. Hon. Gordon Brown MP Chancellor of the Exchequer at a DfID/UNDP Seminar "Words into Action, in 2005." Lancaster House, London, 26 January, 2005.

www.hm-treasury.gov.uk/newsroom_and_speeches/press/2005/press_03_05.cfm

Buckman, G. (2005). Global Trade: Past Mistakes, Future Choices. London: Zed Books.

Christian Aid (2004). 'London. Curch House Publishing' At https://exeter.anglican. org/wp-content/uploads/2014/12/Trade-Justice-A-Christian-Reponse-to-GlobalPoverty.pdf

Clark, P. (1994). 'US Trade Strategy Favours Latin America.' 9, GAO. Ch. 1, Age, 7 July.

Cohen, B.J. (1997). 'The Political Economy of Currency Regions' in the Political Economy of Regionalism (eds. Edward D. Mansfield \&Helen V. Milner) New York: Columbia University Press.

Cohen, M. (1994). 'Negotiation in the New Economic Environment: The Damages in International Trade Agreements' Mimeo, Simon Fraser University, Burnaby, Canada.

Copson, R W. (2005). 'Africa, the G8, and the Blair Initiative,' CRS Report RL32796, July 20.

De Vivo, G. (1987).'David Ricardo' in the New Palgrave: A Dictionary of Economics' (eds. John Eatwell, Murray Milgate \& Peter Newman), vol. 4. London: Macmillan Press.

Dollar, D. \& A. Kraay (2001). 'Trade, Growth and Poverty.' World bank Policy Research Department Working Paper No. 2615, (Washington). Posted 20 April, 2016.

Dollar, D. \& A. Kraay (2002). 'World Bank, Globalisation, Growth and Poverty.' World Bank: (Washington). 
Dornbusch, Fischer, S. \& P.A. Samuelson (1977). 'Comparative Advantage, Trade and Payments in a Ricardian Model with a Continuum of Goods' in American Economic Review, 67(5).

Dryden, S. (1995). Trade Warriors, New York: Oxford University Press.

Duina, F. (2016). 'Varieties of Regional Integration: The EU, NAFTA and Mercosur' in Journal of European Integration 28(3): 247-275.

Ekelund, R. B. \& R.F. Hebert (1997). A History of Economic Theory and Method. $4^{\text {th }}$ ed., New York: McGraw-Hill.

Fergusson, I. (2004). 'The Doha Development Agenda: The WTO Framework Agreement'. Congressional Research Service (CRS), Report RL32645, July.

Fergusson, I.F. \& D. Langton (2005). 'U.S. Trade and Investment Relationship with SubSaharan Africa: The African Growth and Opportunity Act and Beyond', CRS Report, RL31772, April.

Fisher, W.F. \& T. Ponniah (eds.) (2003). Another World is Possible: Popular Alternatives to Globalisation at the World Social Forum. London: Zed Books. Available at http:// www.wvi.org

Friends of the Earth International, (2003). 'Towards Sustainable Economies: Challenging Neoliberal Economic Globalisation.' Friends of The Earth International. downloaded from www.foei.org/publications/pdfs/sustain-e.pdf

Froman, M. (2015). "We are at the End of the Line on the Doha Round of Trade Talks," Financial Times, December 13.

GAO (1993). 'North American Free Trade Agreement, United States' General Accounting Office, Report to Congress, Washington DC, September, 2(1).

GATT. (1994a). "The Results of the Uruguay Multilateral Trade Negotiations. Market Access for Goods and Services: Overview of the Results." Geneva, November 1994.

GATT (1994b). General Agreement on Tariffs and Trade 1994, Apr. 15, 1994, Marrakesh Agreement Establishing the World Trade Organisation. Annex 1 A, The Legal Texts: The Uruguay Round of Multilateral Trade Negotiations 17 (1999), 1867 U.N.T.S. 187, 33 I.L.M 1153 (1994).

Gearey, A. (2005). 'Globalisation and Law, Trade, Rights, War', Rowman and Littlefield publishers.

George, C. \& C. Kirkpatrick (2004). 'Trade and Development: Assessing the Impact of Trade Liberalization on Sustainable Development' in Journal of World Trade, 38(3):441-469.

Gray, J. (1995). Enlightenment's Wake: Politics and Culture at the Close of the Modern Age. London and New York: Routledge.

Gray, J. (1998). False Dawn - the Delusions of Global Capitalism, London: Granta Books.

Hardt, M. \& A. Negri (2001). Empire. Cambridge, Mass: Harvard University Press.

Hatchard, J. \& A. Perry-Kessaris (eds.) (1993). Law and Development: Facing Complexity in the $21^{\text {st }}$ Century. London: Cavendish Publishing.

Hanrahan, C.E. (2005). 'Agriculture in the WTO Doha Round: The Framework Agreement and Next Steps.' CRS Report RS 21905, May.

Hines, C. \& T. Lang (1993). The New Protectionism: Protecting the Future against Free Trade. London: Earthscan.

Hines, C. (2000). Localisation: A Global Manifesto. London: Earthscan.

Hobbes, T. [1651] Leviathan (ed. R. Tuck). Cambridge: Cambridge University Press.

Hoekman, B., A. Mattoo \& P. English (eds.) (2002). 'Development, Trade and the WTO: A Handbook.' Washington D.C. World Bank. 
Hudec, R. (1990). 'Mirror, Mirror on the Wall: The Concept of Fairness in the United States Foreign Trade Policy" Proceedings of the Canadian Council on International law 88.

Hudec, R.E. (1987). 'Developing Countries in the GATT Legal System', London: Trade Policy Research Centre,

Hufbauer, G. \& J. Schott (1992). 'NAFTA: An Assessment, Institute for International Economics', Washington DC.

Hirschman, A.O. (1987). The Passions and the Interests: Political Arguments for Capitalism before Its Triumph. Princeton University Press.

Igwe, I.O. (2011). 'The International Trade Law Context of Textile \& Clothing: Old Constraints and New Challenges', in BIU Law Journal 1(1):146-185.

Igwe I.O.C. (2019). 'Recognising the Various Trends of Globalisation: Inequality in International Economic Relations' in Athens Journal of Law 5(1):1-22.

IMF (1997). 'International Monetary Fund.' World Economic Outlook. IMF, Washington.

IMF (2000). 'Debt Relief, Globalisation and IMF Issues Brief.' IMF, New York. Available at www.imf.org

Kennedy, P. (1988). The Rise and Fall of Great Powers: Economic Change and Military Conflict from 1500 - 2000. London: Fontana Press.

Keynes, J.M. (1936). The General Theory of Employment, Interest, and Money. London: MacMillan.

Khor, M. (2000). 'Rethinking Liberalisation and Reforming the WTO' in Third World Economics, 227:10-15.

Khor, M. (2003). 'Globalisation, Global Governance and the Dilemmas of Development' I, Ha-Joon Chang (ed.) Rethinking Development Economics. London: Anthem.

LaHaye, L. 'Mercantilism' in The Concise Encyclopedia of Economics, Liberty Fund, Inc. 1999-2004.

Lester, S. (2016). 'Is the Doha Round Over? The WTO's Negotiating Agenda for 2016 and Beyond'. CATO Institute: Free Trade Bulletin No. 64.

Lim, L. (2005). 'Tangled of Protectionism', Part III, Yale Global Online, 10 May. available at https://yaleglobal.yale.edu/content/tangled-threads-protectionism-part-iii; accessed 07/11/2018

Lowenfeld, A.F. (2002). International Economic Law. Oxford: Oxford University Press.

Malhotra, K., Bahadur, C., Jahan, S. \& M. Keklik (2003). 'Making Global Trade Work for People.' New York: UNDP \& Earthscan..

Marx, K. (1976). Speech on the Question of Free Trade delivered to the Democratic Association of Brussels At it Public Meeting of January 9, 1848 in Karl Marx \& Frederick Engels, Collected Works, Volume 6, Lawrence \& Wishart: London.

McArthur, J. \& K. Rasmussen (2017). 'How Successful were the Millenium Development Goals?' in The Brookings Institutions.

McCord, N. (1970). Free Trade: Theory and Practice from Adam Smith to Keynes, David \& Charles, Newton Abbot.

McLaughlin, K. (2012). 'Malaria is not going away because we are getting fake treatment.' The Guardian. Sunday 23 December.

Melamed, C. (2002). 'What Works? Trade, Policy and Development', Christian Aid, London.

Mill, J.S. (1848). Essays on Some Unsettled Questions of Political Economy. London: Parker.

Milner, C.R. (2006). 'Making NAMA Work: Supporting Adjustment and Development' in The World Economy 29:1409-1422.

Milner, C.R. \& E. Zgovu, (2006). 'A Natural Experiment for Identifying the Impact of 'Natural' Barriers on Exports' in Journal of Development Economics 80(1):251-268. 
Monbiot, G. (2003). The Age of Consent: A Manifesto for a New World Order. London: Flamingo.

Moore, M. (2003). A World without Walls: Freedom, Development, Free Trade and Global Governance. Cambridge: Cambridge University Press.

Neil, T. (2007). 'Global Capitalism, the Anti-Globalisation Movement and the Third World.' (Author Abstract), Capital \& Class, Summer.

OECD (1998). Organisation for Economic Cooperation and Development. "Open Markets Matter: The Benefits of Trade and Investment Liberalisation." OECD, Paris.

Oxfam International (2002). Rigged Rules and Double Standards: Trade, Globalisation and the Fight against Poverty. Washington, DC: Oxfam.

Parris, B. (1999). 'Trade for Development - Making the WTO Work for the Poor', World Vision, East Burwood (Australia).

Polanyi, K. (1994). The Great Transformation: The Political and Economic Origins of our Time. Boston: Beacon Press.

Porter, M. (1990). The Comparative Advantage of Nations. London: Macmillan.

Punch News (2017). 'Editorial Board, Nigeria, dumping ground for fake imports.' March 12.

Ricardo, D. (1817). On the Principles of Political Economy and Taxation. Harmondsworth: Penguin University of Pennsylvania Press, 1971.

Rothbard, M. (1995). Classical Economics: An Austrian Perspective on the History of Economic Thought, vol. 2, Hants, UK: Edward Elgar.

Rohmann, C. (2002). The Dictionary of Important Ideas and Thinkers. London: Arrow Books.

Ruggie, J.G. (1982). 'International Regimes, Transactions, and Change: Embedded Liberalism in the Post-war Economic System' in International Organisation 36(2): 379-415.

Ruggiero, R. (1996).'Managing a World free Trade and Deep Interdependence' Address to the Argentinean Council on Foreign Relations, Bueonos Aires, on September 10.

Available at http://www.wto.org/wto/english/news_e/press96_e/pro55_e.htm

Schumpeter, J. (1928). 'The Instability of Capitalism' in Economic Journal 38:361-386, 123:297-307.

Schonhardt-Bailey, C. (2006). 'From the Corn Laws to Free Trade: Interests, Ideas and Institutions in Historical Perspective', MIT Press.

Smith, A. (1776). An Inquiry into the Nature and Causes of the Wealth of Nations.

Glasgow edition of the works and correspondence of Adam Smith. Oxford: University Press, 1976.

Stiglitz, J. \& A. Charlton (2004). 'A Development Round of Trade Negotiations in the

Aftermath of Cancun.' A report for the Commonwealth Secretariat, Published by Commonwealth Secretariat United Kingdom, 2004, note 23, p. 17.

Stiglitz, J. \& A. Charlton (2005). Fair Trade for all: how trade can promote development. Oxford New York: Oxford University Press.

Torrens, R. (1844). The Budget' on Commercial and Colonial Policy. London: Smith, Elder.

Economists (1994). 'War of Words.' The Economists, October 1.

UNCTAD (1999). United Nations Conference on Trade and Development Report. United Nations: New York and Geneva.

UNCTAD (2011). United Nations Conference on Trade and Development: Rules of Origin and Origin Procedures Applicable to Exports from Least Developed Countries. United Nations: New York and Geneva.

UNDP (1999). The United Nations Development Programmes Human Development Report. 
Watkins, K. \& P. Fowler (2002). Rigged Rules and Double Standards: Trade, Globalisation and the Fight Against Poverty. Oxfam Publishing.

Wiesbort, M. \& D. Baker (2002). The Relative Impact of Trade Liberalisation on Developing Countries. Centre for Economic and Policy Research, Washington.

Woodin. M. \& C. Lucas (2004). Green Alternatives to Globalisation: A Manifesto. London: Pluto Press.

World Bank (1997). The State in a Changing World, 1997 World Development report. New York: Oxford University Press.

WTO (1994). GATS: General Agreement on Trade in Services, April 15, 1994, Marrakesh Agreement Establishing the World Trade Organisation, Annex 1B, The Legal Texts: The Results of the Uruguay Round of Multilateral Trade Negotiations 284 (1994) 1869 U.N.T.S. 183, 33 I.L.M. 1167 (1999).

WTO (2000a). World Trade Organisation: Special Study No. 5, 'Trade, Income, Disparity and Poverty'.

WTO (2000b). World Trade Organisation: Press Releases - Press/181, 13 June 2000 at https://www.wto.org/english/news_e/pres00_e/pr181_e.htm

WTO (2001). World Trade Organisation: Doha WTO Ministerial Conference, 9-13 November 2001, adopted on 14 November.

WTO (2003). World Trade Organisation. Trade and Trade Policy Developments.

World Trade Report. WTO, Geneva, 1 July 2003. https://www.wto.org/english/res_e/boo ksp_e/anrep_e/world_trade_report_2003_e.pdf

WTO (2004). World Trade Organisation: Doha Development Agenda, July Package 2004,' WT/L/579, adopted 2 August 2004. https://www.wto.org/english/tratop_e/ dda_e/dda_package_july04_e.htm

WTO (2009). Multilateral zing Regionalism: Challenges for Global Trading System. WTO, February 2009. www.wto.org

WTO (2017). Recent Development in Regional Agreements. WTO, July - December 2017. 
